\title{
REACTIVE OXYGEN SPECIES IN SIGNAL TRANSDUCTION
}

\author{
L. B. DROBOT', A. A. SAMOYLENKO', A. V. VOROTNIKOV ${ }^{2}$, P. A. TYURIN-KUZMIN', \\ A. V. BAZALII', T. KIETZMANN ${ }^{3}$, V. A. TKACHUK ${ }^{2}, S$. V. KOMISARENKO \\ ${ }^{1}$ Palladin Institute of Biochemistry, National Academy of Sciences of Ukraine, Kyiv; \\ e-mail:drobot@biochem.kiev.ua \\ ${ }^{2}$ Lomonosov Moscow State University, Faculty of Basic Medicine, Russia; \\ ${ }^{3}$ Department of Biochemistry and Biocenter Oulu, University of Oulu, Oulu, Finland;
}

Reactive oxygen species (ROS) are products of incomplete reduction of oxygen both nonradicals and radicals that function as mediators of redox signaling and oxidative stress depending on their levels in different subcellular compartments. Up to date, a huge body of data are accumulated, which supports a role of ROS as "second messengers" in intracellular signaling cascades that control cell growth, proliferation, apoptosis as well as migration and invasion. The current review summarizes data regarding $R O S$-dependent regulation of signaling networks components including MAPK, PI3K/Akt, PKC, NF- $\mathrm{B}, \mathrm{Nrf2}$, FoxO and HIF-1 $\alpha$, and role of ROS in tumorigenesis.

Key words: ROS, redox-dependent signaling, carcinogenesis.

$\mathrm{T}$ here is much evidence that ROS affect the major cell signaling cascades [1-3]. Their effect is based primarily on the fact that some ROS can modify the "redox"-sensitive residues in signaling protein molecules. The best studied is the reaction of ROS with cysteine residues, especially in the active sites of enzymes [4]. Accordingly, growth factors, hormones and clotting factors, including platelet-derived growth factor (PDGF), angiotensin II and insulin use ROS, at least in part, as intracellular messengers. Thus, the accumulation of ROS in cells may mimic the effects of these ligands and lead to ligand-independent modulation of many signaling cascades.

Often ROS-dependent signaling involves MAPKs (mitogen-activated protein kinases) and/ or PI3K (phosphatidylinositol-3-kinases)/Akt. In addition, the activity of other protein kinases, including protein kinase $\mathrm{C}$ (PKC), JNK (Janus kinase) and ATM (ataxia-telangiectasia mutated), may be modulated by the action of ROS [3, 5-7]. Other important targets of ROS are protein tyrosine phosphatases (PTP). Catalytic oxidation of cysteine residues in the molecules of PTPs leads to their reversible inactivation [8]. Both ligandindependent changes in intracellular redox state and increased formation of ROS when exposed to extracellular stimuli can cause oxidation of PTPs. Not only classical PTPs that dephosphorylate specific phosphotyrosine or phosphoserine/phosphothreonine residues, but also dual specificity phosphatases able to dephosphorylate phospholipids, may be targets of ROS-dependent oxidation [8]. Some adapter proteins also undergo regulation by the action of ROS. Specifically, p66(Shc) protein that is involved in signal transduction from mem- brane receptors to activated Ras, can be phosphorylated at serine residues under oxidative stress. Accordingly, the cells that do not express p66(Shc) are more resistant to apoptosis induced by $\mathrm{H}_{2} \mathrm{O}_{2}$ [9].

Moreover, it is known that a number of transcription factors can have positive or negative effects on gene expression upon direct or indirect action of ROS. Among such ROS-sensitive transcription factors are NF- $\mathrm{B}$ (nuclear factor kappa B), Nrf2 (nuclear factor erythroid-2-related factor-2), SP1, Ref-1 (redox factor-1), cJun, HIF-1 $\alpha$ (hypoxia inducible factor-1 $\alpha$ ) and HIF-2 $\alpha$ [10-12]. Moreover, a number of tumor suppressors such as p53, FoxO (forkhead box O), RB (retinoblastoma protein), p21, p16, BRCA1 and BRCA2 (breast cancer susceptibility genes 1 and 2), play a role in activating the expression of genes encoding antioxidant enzymes, including MnSOD and catalase, in response to oxidative stress [3].

Among various signaling pathways and transcription factors that are regulated by the action of ROS, MAPK, PI3K/Akt, PKC, NF- $\mathrm{B}$, Nrf2, FoxO and HIF- $1 \alpha$ are among the best studied and will be covered in more detail in our review.

\section{MAPK signaling pathways}

MAPK kinases are involved in the regulation of expression of genes responsible for cell proliferation, motility, substrate-independent growth, differentiation and apoptosis. The three main groups of MAPK, such as ERK-1/2 (extracellular signal-regulated kinases), JNK1/2/3 (c-Jun NH2terminal kinase) and $\mathrm{p} 38(\mathrm{p} 38 \alpha / \beta / \gamma / \delta)$, are best described. Although the detailed mechanisms are not fully known, ROS can initiate the activation of 
ERK and JNK cascades, causing autophosphorylation of growth factors receptors, such as EGFR (epidermal growth factor receptor) and PDGFR, in a ligand-dependent manner [13]. Furthermore, it was shown that the various components of the major MAPK signaling cascades can respond to changes in intracellular levels of ROS. In particular, the direct activation of ERK1/2 cascade can be achieved by oxidative modification of Ras at cysteine residue 118 [14]. This modification inhibits GDP/GTP exchange, thereby activating Ras. In addition, ROS also have an indirect effect on the activation of ERK1/2. For example, it influences the activity of MEK1/2 kinase, which phosphorylates ERK1/2. It was also shown that ROS can promote proteasomal degradation of ERK1/2 negative regulator phosphatase MKP3 (mitogen-activated protein kinase phosphatase), thereby activating ERK1/2 [15].

In addition, oxidative stress can activate JNK1-3 [16]. JNKs were first discovered by the ability to bind and phosphorylate protein c-Jun, which is a component of the transcription complex AP-1 (activator protein-1). ROS can regulate AP-1 via several mechanisms. Experiments in vitro have shown that cysteine residues 154 in c-Fos and cysteine 272 in c-Jun are sensitive to ROSdependent oxidation. Both proteins can be inactivated by oxidation of these cysteines [17]. Furthermore, it was shown that nuclear protein Ref-1 promotes DNA-binding activity of AP-1 through a redox modification of cysteine residues in the DNA-binding domains of Fos and Jun [18]. Redox regulation of AP-1 via JNK cascade can also be achieved with the participation of Trx (thioredoxins). In particular, Trx is a binding partner of ASK-1 (apoptosis signal-regulating kinase 1), which activates JNK and p38 pathways [19]. ROS violate the stability of the complex ASK1-Trx by oxidation and activation of ASK1 [20], followed by activation of JNK and p38. Thus, AP-1 is a transcription factor that may be modified either directly in redox-dependent reactions, or indirectly through upstream redox-sensitive components of signaling pathways.

Beside c-Jun, more than 50 other substrates of JNK were identified. Activated JNK is associated in particular with the regulation of cell death, since antiapoptotic proteins Bcl-2, Bcl-XL and Bad can be phosphorylated by the action of JNK [21, 22]. When JNK phosphorylates Bcl-2 or Bcl-XL, this leads to inhibition of their activity and loss of antiapoptotic functions. Activated JNK, in addition to inhibition of Bcl-2, also increases the levels of proapoptotic protein Bax [23]. As a result, the ratio of $\mathrm{Bax} / \mathrm{Bcl}-2$ changes in favor of $\mathrm{Bax}$, then the outer mitochondrial membrane becomes more permeable leading to cytochrome c release, caspase cascade activation and induction of apoptosis. Simultaneously, the mitochondrial superoxide is released into the cytosol, where it turns into $\mathrm{H}_{2} \mathrm{O}_{2}$ by the action of $\mathrm{Cu} / \mathrm{Zn}$ SOD. It was recently shown that these ROS cause translocation of serine/threonine protein kinase D1 (PKD1) from the Golgi complex into mitochondria. PKD1, in turn, can inhibit JNK and activate antiapoptotic effects of transcription factor $N F-\kappa B$ and induce expression of antioxidant enzymes [24].

Another important inducer of JNK activity either by direct interaction or by oxidation-sensitive mechanism is HNE (4-hydroxy-2-nonenal), a stable product of lipid peroxidation [25, 26]. HNAinduced activation of $\mathrm{JNK}$ is $\mathrm{H}_{2} \mathrm{O}_{2}$-dependent in rat liver RL34 cells. Moreover, HNA forms adducts with $\mathrm{JNK}$, leading to nuclear translocation and activation of this kinase in hepatic stellate cells $[25,26]$.

The p38 kinases have been first identified as modulators of TNF (tumor necrosis factor) signaling [27]. Later it was found that activation of p38 MAPKs occurs by the action of many other stimuli, including hormones, oxidative stress, osmotic and heat shock, which are often accompanied by the formation of $\mathrm{H}_{2} \mathrm{O}_{2}$. At least four representatives of $\mathrm{p} 38$ kinase family $(\alpha, \beta, \gamma$ and $\delta)$ are identified. Among them the enzyme p38 $\alpha$ is best characterized. It was shown that $\mathrm{H}_{2} \mathrm{O}_{2}$ activates $\mathrm{p} 38$ pathway in various cell types [28]. On the other hand, a recent study showed that $\mathrm{H}_{2} \mathrm{O}_{2}$ can inhibit the activity of p38, despite the increased phosphorylation of the kinase. It was demonstrated that in response to $\mathrm{H}_{2} \mathrm{O}_{2}$ and prostaglandin $\mathrm{J} 2$ treatment cysteine residues 119 and 162 near the surface of the p38 molecule are oxidized [29].

\section{PI3K/Akt signaling pathway}

Protein kinase B (PKB), also known as Akt because of its homology with the oncogene v-Akt, is a serine/threonine kinase that plays a key role in many cellular processes and is often overexpressed in different types of tumors. Non-physiological activation of Akt leads to increased angiogenesis, metastasis, insensitivity to the action of growth factors and inhibition of apoptosis in tumor cells [30]. Three isoforms of Akt, PKB $\alpha / A k t 1, P K B \beta /$ $\mathrm{Akt} 2$ and $\mathrm{PKB} \gamma / \mathrm{Akt} 3$, were described. The isoform $\mathrm{PKB} \alpha$ is predominant in most cell types. Akt, which is activated by the action of PI3K, regulates, directly or indirectly, the activity of many transcription factors such as CREB (cAMP response element-binding) or FoxO [30, 31].

ROS, such as $\mathrm{H}_{2} \mathrm{O}_{2}$, can activate Akt in various cell types, including NIH 3T3, HEK293, 
HeLa and Jurkat cells [32]. Under conditions of oxidative stress activation of Akt can be achieved either directly or indirectly through participation of other kinases. It is known that $\mathrm{H}_{2} \mathrm{O}_{2}$ can stimulate the activity of MAPKAP kinase-2, p38 substrate, able to phosphorylate PKB/Akt in vitro [33]. Biologically significant concentrations of ROS activate growth factor receptors, including EGFR and PDGFR, which causes stimulation of PKB/Akt signaling pathway [34]. It was also shown that ROS can initiate PKB/Akt phosphorylation through stimulation of cytosolic tyrosine kinase FAK (focal adhesion kinase), which leads to activation of PI3K [34].

The tumor suppressor PTEN (phosphatase and tensin homologue deleted on chromosome 10 ) is an important inhibitor of PI3K. Inactivation of PTEN increases the activation of PKB/Akt, and indeed, it was found that ROS may inactivate PTEN through oxidation of cysteine residue 124 [35]. Loss of PTEN leads to further enhancement of oxidative stress by depletion of intracellular peroxiredoxins (Prxs) and $\mathrm{Cu} / \mathrm{Zn}$ SOD [36].

\section{PKC signaling pathway}

The protein kinase $\mathrm{C}$ (PKC) family consists of a number of isoforms containing regulatory and catalytic domains, respectively, in the amino- and carboxy-terminal parts of their molecules. PKC isoforms are divided into three subgroups, cPKC (conventional), nPKC (novel), and aPKC (alternative), based on the structural characteristics of their regulatory domains [37]. PKC isoforms that regulate a wide range of cellular processes, including proliferation, differentiation and apoptosis, are involved in the development of various forms of cancer. Several agonists and antagonists of PKC are examined as potential anticancer agents [37].

The activity of some PKC isoforms is modulated by the action of ROS. For example, isoforms $\alpha, \beta \mathrm{I}$ and $\gamma$ of cPKC, $\delta$ and $\varepsilon$ of nPKC and $\zeta$ of aPKC are activated after the addition of $\mathrm{H}_{2} \mathrm{O}_{2}$ to the cells [38]. Most probably, conservative cysteinerich regions of PKC $\alpha$, which may be sensitive to ROS and are responsible for binding of diacylglycerol, are also involved in the activation of PKC [39].

\section{Transcription factor NF-кB}

Members of the $\mathrm{NF}-\kappa \mathrm{B}$ transcription factor family are homodimers or heterodimers formed by several related proteins such as p50, p52, RelA (p65), Rel B and c-Rel. They all contain a domain homologous to Rel, which mediates dimerization, specific DNA recognition and interaction with inhibitory subunit $(\mathrm{I} \kappa \mathrm{B})$. Isoforms of $\mathrm{I}_{\kappa} \mathrm{B}(\mathrm{I} \kappa \mathrm{B} \alpha$, $\mathrm{I} \kappa \mathrm{B} \beta, \mathrm{I} \kappa \mathrm{B} \gamma(\mathrm{p} 105), \mathrm{I} \kappa \mathrm{B} \delta(\mathrm{p} 100), \mathrm{I} \kappa \mathrm{B} \varepsilon$ and $\mathrm{BCL}-3$ [40] prevent nuclear translocation of NF- $\kappa \mathrm{B}$ homoand heterodimers. In general, NF- $\kappa \mathrm{B}$ is activated and transported into the nucleus after degradation of $\mathrm{I} \kappa \mathrm{B}$ subunit as a result of phosphorylation and ubiquitylation [40]. There are two main pathways that activate NF- $\mathrm{BB}$, canonical and non-canonical, the first being stimulated by pro-inflammatory receptors (TNF receptor family, TLR (Toll-like receptors) and cytokine receptors), and the second activated by those members of TNF family receptors that bind TRAF (TNF receptor associated factor) proteins [41]. The $\mathrm{NF}-\kappa \mathrm{B}$ transcription factors are involved in regulating the expression of hundreds of genes related to immune response, cell growth, differentiation, and apoptosis [42]. Therefore, as expected, constitutive activation of NF- $\kappa$ B is found in various forms of cancer [43].

Activation of $N F-\kappa B$ is often associated with the formation of ROS, since a number of stimuli that activate $\mathrm{NF}-\kappa \mathrm{B}$ can also cause ROS formation. It has been shown that ROS are mediators in the phosphorylation of $\mathrm{I}_{\kappa} \mathrm{B} \alpha$-specific kinases IKK $\alpha$ and IKK $\beta$, resulting in the release of NF$\kappa \mathrm{B}$ dimers, which further are translocated to the nucleus [44]. In addition, protein kinase Tak1, which activates IKK by phosphorylation, is redoxsensitive [41]. As another example, TNF $\alpha$ initiates a redox-dependent phosphorylation of serine 276 residue in the RelA molecule. Later it was found that phosphorylation of this residue, required for activation of $N F-\kappa B$, can be mediated by the catalytic subunit of PKA, whose activity is regulated by the ROS action [45]. It is also known that NF- $\mathrm{BB}$ can be activated by the action of PKC and MAPK [46, 47], which, as described above, are regulated by ROS. Unlike other effects of ROS leading to activation of $\mathrm{NF}-\kappa \mathrm{B}$, it was shown that oxidation of cysteine residue 62 in the p50, another member of NF- $\kappa \mathrm{B}$ family, reduces its ability to bind DNA [48-50]. In addition, there is evidence that the impact of ROS on the activity of NF- $\kappa \mathrm{B}$ may depend on intracellular compartment: ROS stimulate $\mathrm{NF}-\kappa \mathrm{B}$ in the cytoplasm, but inhibit its activity in the nucleus [51].

$\mathrm{NF}-\kappa \mathrm{B}$ regulates the expression of many genes that encode antioxidant enzymes, e.g. SOD, GPX1, Trx-1, Trx-2, HO-1 and ferritin heavy chain. Playing an important role in inflammation, $\mathrm{NF}-\kappa \mathrm{B}$, on the other hand, controls the expression of a number of "prooxidant" genes such as NOX2, XOR (xanthine oxidoreductase), inducible NO-synthase, cyclooxygenase-2 and lipooxygenase [41]. Thus, activation of NF- $\kappa \mathrm{B}$ can differentially regulate the redox state of the cell, depending on the stimulus. 


\section{Transcription factor FoxO}

Transcription factors of FoxO (forkhead box $\mathrm{O}$ ) family belong to a large group of proteins, which are characterized by conservative Fox (forkhead box) DNA-binding domain [52]. The FoxO family in mammals includes four proteins, FoxO1, Foxo3a, FoxO4 and FoxO6, the expression of which varies depending on the tissue type. FoxO proteins play a key role in many cellular processes, including proliferation, differentiation, apoptosis, DNA damage and resistance to stress [3].

The activity of FoxO transcription factors, which is largely controlled by insulin/PI3K/Akt signaling cascade, may be regulated by the action of ROS at different levels. It has been shown that ROS affect the transcriptional activity of FoxO, influencing a number of post-translational modifications, such as phosphorylation, acetylation and ubiquitylation [53]. ROS can as well influence the activity of FoxO indirectly by activation of Akt, ERK, JNK, p38 and IKK depending on the cell type, duration and intensity of the accumulation of ROS [3]. Recently, it was found that ROS also cause oxidation of cysteine residues in FoxO, thereby directly affecting the activity of this transcription factor [54]. Activation of FoxO upon ROS action can cause cell cycle arrest and removal of ROS through activation of antioxidant enzymes, including MnSOD and catalase [3].

\section{Transcription factor Nrf2}

Another target of ROS is bZIP Cap'n'Collar transcription factor $\mathrm{Nrf2}$, which can integrate a variety of cellular responses to oxidative stress. Under normal conditions, Nrf2 forms an inactive complex in the cytoplasm with the cytoskeletal protein Keap1 (Kelch-like ECH-associated protein 1) leading to ubiquitylation and proteasomal degradation of Nrf2 [55]. Under conditions of oxidative stress kinase PERK (double stranded RNA-activated protein kinase-like ER kinase) is activated, which causes phosphorylation of Nrf2, dissociation of the Nrf2-Keap1 complex and transport of Nrf2 to the nucleus [56]. After heterodimerization with other transcription factors, Nrf2 activates the transcription of genes that contain ARE (antioxidant response elements) [57]. ARE regulates the expression of genes involved in antioxidant defense, such as genes for glutathione S-transferase (GST) A1 and A2, $\gamma$-glutamylcysteine synthetase, heme oxygenase-1, NAD(P)H:quinone oxidoreductase and UDP-glucuronosyl transferase [57].

Moreover, ROS can also act at the level of Keap1. The ability of Nrf2 to bind Keap1 is regulated via critical cysteine residues 151, 273 and
288, which are essential for Keap1-dependent ubiquitylation and proteasomal degradation [58]. Thus, there are two mechanisms of Nrf2 activation: Direct phosphorylation of Nrf2 by PERK, PKC, MAPK and PI3K [59] and modification of cysteine residues in Keap1, which prevents proteasomal degradation of Nrf2 [58].

\section{Transcription factors HIFa}

Transcription factor HIF is a dimer composed of $\alpha$-subunit and $\beta$-subunit, also known as ARNT (arylhydrocarbon receptor-nuclear translocator). Both subunits belong to the family of transcription factors bHLH-PAS, containing domains bHLH (basic helix - loop - helix) and PAS (PerARNT-Sim). Among three different $\alpha$-subunits of HIF, known to date, HIF- $1 \alpha$ and HIF- $2 \alpha$ are key regulators of the expression of physiologically important genes induced by hypoxia. The processes regulated by the action of HIF include glucose metabolism, erythropoiesis, angiogenesis, cell survival and proliferation. Despite the fact that HIF-2 $\alpha$ 's structure is similar to that of HIF-1 $\alpha$, the functions of HIF-2 $\alpha$ and HIF-1 $\alpha$ vary depending on the cell type [60]. In contrast, HIF-3 $\alpha$ is not an effective stimulator of gene expression by hypoxia and may even act as a repressor [61, 62].

Intracellular amount of HIF-1 is controlled mainly at the post-translational level by regulating the stability of the $\alpha$-subunit of the protein. The stability of $\alpha$-subunits and their activity is dependent on hydroxylation of, respectively, proline and asparagine residues. At normal intracellular oxygen concentrations two proline residues (402 and 564) of HIF-1 $\alpha$ subunit are hydroxylated by specific prolyl hydroxylases PHD1-4 (prolyl hydroxylase domain) [63-65]. Hydroxylation enables protein VHL (von Hippel-Lindau tumor supressor protein), which is a component of the E3 ubiquitin-ligase complex, to bind HIF-1 $\alpha$ and stimulate its ubiquitylation and further proteasomal degradation $[66,67]$. In addition, asparaginyl hydroxylase FIH-1 (factor inhibiting HIF-1) under normoxia catalyze hydroxylation of asparagine residues in the $\alpha$-subunit of HIF, which prevents them from binding transcription activator CBP (cAMP-response element-binding protein)/p300 [68]. Since hydroxylation reaction is oxygen-dependent, it does not occur under hypoxia. After HIF-1 $\alpha$ escapes degradation in the proteasome and recruits $\mathrm{CBP} / \mathrm{p} 300$, it accumulates, translocates to the nucleus and forms there a complex with HIF-1 $\beta$ [69]. The resulting heterodimer binds to promoter HRE (hypoxia response element) sequences and induces expression of the corresponding genes. 
It is known that the addition of $\mathrm{H}_{2} \mathrm{O}_{2}$ to the cells that grow under conditions of hypoxia leads to destabilization of HIF-1 $\alpha$ [70] and HIF-2 $\alpha$ [71]. These data fit well into the concept of the important role of ROS in HIF-dependent signaling. Both direct and indirect redox-dependent processes that regulate intracellular content of HIF-1 and HIF-2 were described. The target of direct ROS-dependent regulation is the C-terminal domain of HIF, in which cysteine residues 800 (for HIF-1) and 848 (for HIF-2) are necessary for transactivation [72]. Oxidation/reduction of these cysteine residues depends on the activity of redoxdependent factor Ref-1 [73]. In addition to the Ref-1, other coactivators, including SRC-1 (steroid receptor coactivator-1) and TIF2 (transcription intermediary factor 2), interact with the C-terminal domain of HIF-1 and HIF-2 in ROS-dependent manner [73]. Indirect regulation of HIF-1 upon ROS action is mainly due to the changes in the activity of PHD and redox-sensitive kinases and phosphatases [74].

The PI3K/Akt and MAPK cascades, that are dependent on the action of ROS (see above), can also affect HIF $\alpha$ levels [75]. Accordingly, antioxidants and inhibitors of NADPH oxidase prevent PI3K/Akt-dependent HIF-1 $\alpha$ activation [76]. In addition, ERK1/2 can phosphorylate HIF-1 $\alpha$ [75] and contribute to induction of HIF-1 upon the action of multiple stimuli that increase the formation of ROS, such as angiotensin II [77], prostaglandin E2 [78] and shock waves [79]. However, it should be remembered that the sensitivity of ERK1/2 to ROS and subsequent induction of HIF- $1 \alpha$ depends on the cell type and stimulus [76, 79]. The components of p38 kinase signaling pathway, such as MKK3 and MKK6 [80], are also involved in the induction of HIF- $1 \alpha$ upon the action of thrombin [76] and chromium (VI) [81]. Finally, phosphatases such as MKP-1 and MKP-3 and protein phosphatase-2 may be regulated by the action of ROS and affect the activity/stability of HIF-1 $\alpha$ $[82,83]$.

\section{The dual role of ROS in the carcinogenesis}

In general, the mechanisms of ROS-dependent regulation of key intracellular signaling pathways are complex and require further study. The role of each of these pathways in the process of carcinogenesis can be very complex [84-86]. In short, depending on the kinetics of activation and inactivation, intracellular localization, the formation of complexes with protein partners, as well as the presence of substrates, these pathways have a significant impact on cell cycle, apoptosis, survival, angiogenesis, invasion and metastasis [87].
Although ROS, when accumulated above physiological levels, are not always harmful to the cell, it happens in many cases due to mutations of oncogenes and tumor suppressor genes, and also because of the induction of signaling pathways responsible for carcinogenesis. However, the overall picture of the ROS role in the process of malignant transformation of cells is rather complex. While a moderate increase in ROS levels induces tumor growth, excessively high levels of ROS can inhibit carcinogenesis [88]. Several studies have demonstrated the ability of ROS to induce apoptosis in cancer cells, and also found that high levels of ROS correlated with decreased proliferation of transformed cells, decreased angiogenesis and metastasis [87]. One of the possible ways to inhibit cell proliferation when exposed to elevated concentrations of ROS is p16-dependent activation of PKC $\delta[89,90]$. In addition, various types of ROS can sometimes reveal the opposite effect. For example, $\mathrm{O}_{2}{ }^{--}$and $\mathrm{H}_{2} \mathrm{O}_{2}$ inhibit the invasion and migration of human lung carcinoma $\mathrm{H} 460$ cells, whereas ${ }^{\circ} \mathrm{OH}$ increases the migratory and invasive properties of the cells of this type [91].

The "threshold concept" in the treatment of cancer suggests that it is possible to achieve a specific accumulation of ROS in cancer cells to the levels that trigger cell death [88, 92]. In accordance with this concept, a recent study showed that alkaloid piperlongumine increases the levels of ROS and apoptosis in cancer cells, but has little effect on untransformed cells, regardless of their proliferation rates [93]. Therapeutic strategies based on the use of ROS both as inducers and inhibitors of carcinogenesis have been developed [86, 94, 87]. For example, the drug procarbazine in aqueous solutions undergoes oxidation, which enhances the production of $\mathrm{H}_{2} \mathrm{O}_{2}$ to concentrations that are cytotoxic [95]. Now procarbazine is allowed for the treatment of lymphomas and melanomas [87]. Another chemotherapeutic agent, which enhances the production of $\mathrm{O}_{2}^{--}$in cancer cells, is $\mathrm{As}_{2} \mathrm{O}_{3}$ [96]. Like many chemotherapeutic drugs, radiation therapy stimulates the formation of ROS, thus eliminating cancer cells from the body [97].

Since many anti-cancer agents act by inducing ROS, antioxidants, reducing levels of ROS, can also promote tumor growth. In particular, it was found that antioxidants improve the survival of cells that have lost the ability to attach to the extracellular matrix [98]. Accordingly, some chemotherapeutic agents do not induce ROS formation but inhibit the action of antioxidants. In particular, $\mathrm{As}_{2} \mathrm{O}_{3}$ irreversibly inhibits thioredoxin reductase (TrxR) in mammals [99]. The inhibitors of SOD are also potential chemotherapeutic agents [87]. 


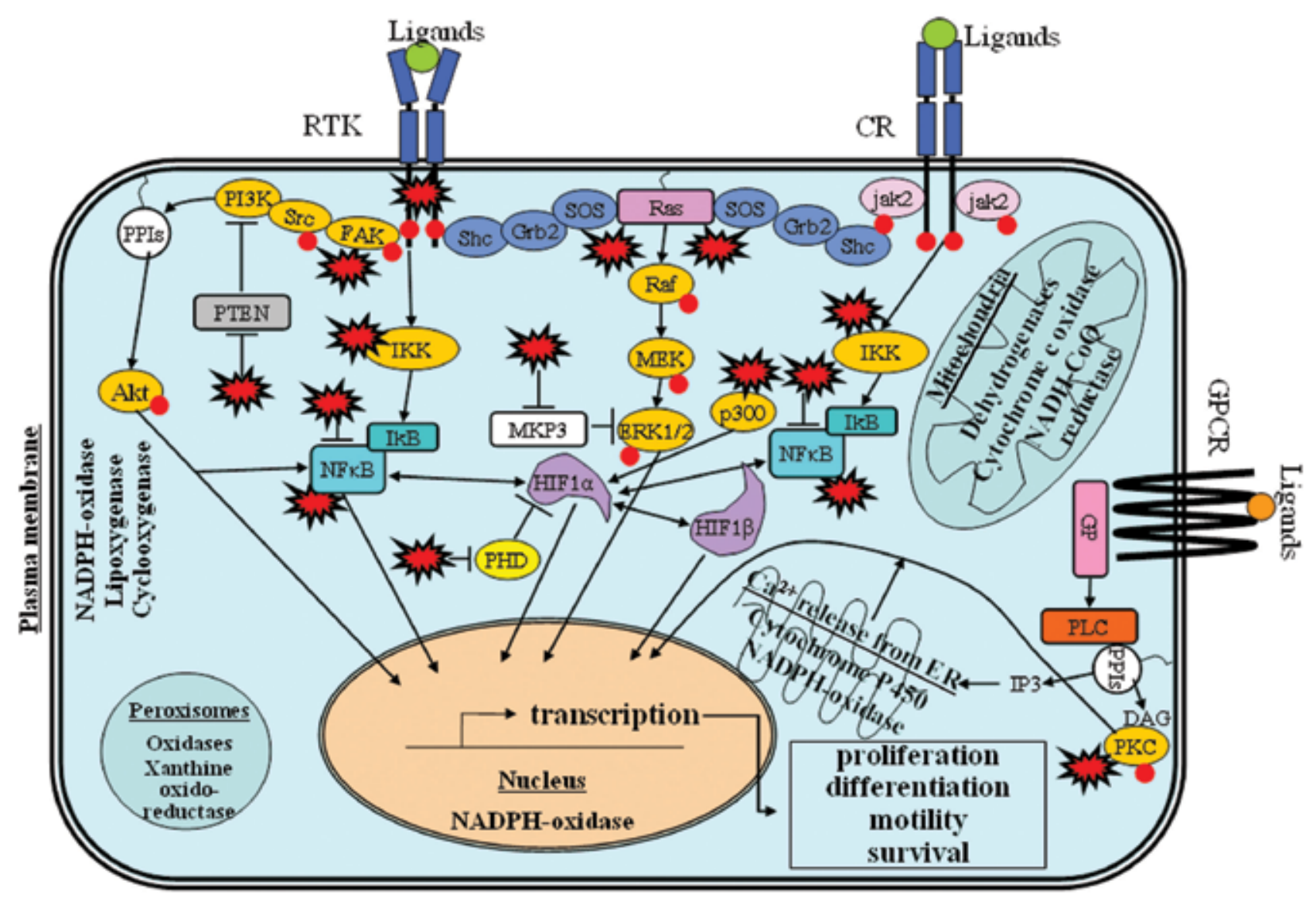

Major intracellular signaling pathways that are regulated by ROS action either positively or negatively. PI3K/ Akt, Ras/ERK, PLC, NF- $\mathrm{B}$ and HIF-1 signaling pathways are presented in a simplified manner. The main physiological sources of ROS in plasma membrane and various intracellular compartments are also indicated. ROS are shown as big star polygons. Phosphogroups are shown as small red circles. The single-head arrows indicate activation, the double-head arrows indicate interaction, and the blunt-end arrows indicate inhibition.

$C R$, cytokine receptors; DAG, diacylglycerol; ERK, extracellular signal-regulated kinase; FAK, focal adhesion kinase; GP, G-protein; GPCR, G-protein coupled receptor; Grb2, growth factor receptor-bound protein 2; HIF-

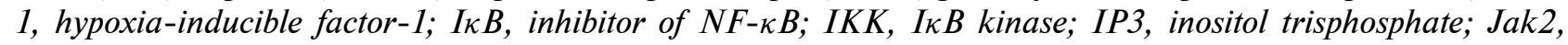
Janus kinase 2; MEK, MAPK/ERK kinase; MKP3, mitogen-activated protein (MAP) kinase phosphatase/ dual specificity protein phosphatase-6; $N F-\kappa B$, nuclear factor kappa-light-chain-enhancer of activated $B$ cells; PHD, prolyl hydroxylase; PI3K, phosphatidylinositol 3-kinase; PI3P, phosphatidylinositol 3-phosphate; PKB/ Akt, protein kinase B; PKC, protein kinase C; PLC, phospholipase C; PPI, polyphosphoinositide; PTEN, phosphatase and tensin homologue deleted on chromosome 10; Raf, ras attachment factor; Ras, Rat sarcoma; RTK, receptor tyrosine kinase; SOS, son of sevenless, guanine nucleotide exchange factor; Shc, SHC (Src homology 2 domain containing) transforming protein; Src, from sarcoma, cytoplasmic tyrosine kinase

On the other hand, there are antitumor drugs that inhibit the production of ROS. For instance, minodronate and histamine dihydrochloride reduce ROS by regulating the activity of NOX $[100,101]$. It is believed that minodronate inhibits the growth of melanoma cells by preventing Ras stimulation, which is ROS mediated [101].

In general, protective or, conversely, carcinogenic effects of ROS depend on the stage of tumorigenesis. For example, since many smokers or people who are constantly exposed to carcinogens (e.g., asbestos workers) may suffer from subclinical cancer, inhibition of ROS levels in cancer cells of these individuals can be harmful. Indeed, studies on the role of low molecular weight antioxidants found that some dietary antioxidant supplements increased cancer incidence and/or mortality in smokers. In particular, increased use of antioxidant $\beta$-carotene has been associated with higher mortality from lung cancer in smokers [102]. 
This work was partially supported by bilateral grant between National Academy of Sciences (NAS) of Ukraine and Russian Fund for Basic Research (RFBR) - 2012.

\section{АКТИВНІ ФОРМИ КИСНЮ У СИГНАЛЬНІЙ ТРАНСДУКЦІї}

Л. Б. Дробот ${ }^{l}$, А. А. Самойленко А. В. Воротніков ${ }^{2}$, П. А. Тюрін-Кузьмін ${ }^{2}$, А. В. Базалій, Т. Кітиманн B. А. Ткачук ${ }^{2}$, С. В. Комісаренко

${ }^{1}$ Інститут біохімії ім. О. В. Палладіна НАН України, Київ; e-mail: drobot@biochem.kiev.ua;

${ }^{2}$ Московський державний університет ім. М. В. Ломоносова, Росія;

зуніверситет Оулу, Оулу, Фінляндія

Активні форми кисню (АФК) є радикальними і нерадикальними продуктами неповного відновлення кисню, що функціонують як медіатори редокс-сигналювання і оксидативного стресу залежно від їх рівня в різних субклітинних компартментах. На сьогодні нагромаджено величезний масив даних, які свідчать на користь функціонування АФК як «вторинних посередників» у регулюванні внутрішньоклітинних сигнальних каскадів, залучених до контролю клітинного росту, проліферації, апоптозу, міграції та інвазії клітин. У цьому огляді узагальнено дані стосовно АФК-залежного регулювання компонентів сигнальних мереж, таких як МАPK, PI3K/Akt, PKC, NF-кB, Nrf2, FoxO, HIF-1 $\alpha$ та ролі АФК у канцерогенезі.

Кл юч ов і слова: АФК, редоксзалежне сигналювання, канцерогенез.

\section{АКТИВНЫЕ ФОРМЫ КИСЛОРОДА В СИГНАЛЬНОЙ ТРАНСДУКЦИИ}

Л. Б. Дробот ${ }^{l}$, А. А. Самойленко ${ }^{l}$,

А. В. Воротников ${ }^{2}$, П. А. Тюрин-Кузьмин ${ }^{2}$,

А. В. Базалий', Т. Китиманн

В. А. Ткачук ${ }^{2}$, С. В. Комисаренко ${ }^{l}$

'Институт биохимии им. А. В. Палладина НАН Украины, Киев; e-mail: drobot@biochem.kiev.ua;

${ }^{2}$ Московский государственный университет им. М. В. Ломоносова, Россия;

${ }^{3}$ Университет Оулу, Оулу, Финляндия

Активные формы кислорода (АФК) являются радикальными и нерадикальными продуктами неполного восстановления кислорода, которые функционируют как медиаторы ре- докс-сигнализации и оксидативного стресса в зависимости от их уровня в различных субклеточных компартментах. К настоящему времени накоплен огромный массив данных, которые свидетельствуют в пользу функционирования АФК как «вторичных посредников» в регуляции внутриклеточных сигнальных каскадов, вовлеченных в контроль клеточного роста, пролиферации, апоптоза, миграции и инвазии клеток. В настоящем обзоре обобщены данные относительно АФК-зависимой регуляции компонентов сигнальных сетей, включая МАРК, PI3K/Akt, PKC, NF-кB, Nrf2, FoxO, HIF-1 $\alpha$ и роли АФК в канцерогенезе.

Ключевые слова: АФК, редоксзависимая сигнализация, канцерогенез.

1. Martindale J. L., Holbrook N. J. // J. Cell Physiol. - 2002. - 192, N 1. - P. 1-15.

2. Morgan M. J., Liu Z. G. // Cell Res. - 2011. 21. - P. 103-115.

3. Vurusaner B., Poli G., Basaga H. // Free Radic. Biol. Med. - 2012. - 52. - P. 7-18.

4. Paulsen C. E., Carroll K. S. // ACS Chem. Biol. - 2010. - 5, N 1. - P. 47-62.

5. Comba A., Lin Y. H., Eynard A. R. et al. // Cancer Metastasis Rev. - 2011. - 30. P. $325-342$.

6. Lauth M. // Front. Biosci. - 2011. - 17. P. 2259-2270.

7. Yao H., Ashihara E., Maekawa T. // Expert Opin. Ther. Targets. - 2011. - 15. - P. 873-887.

8. Ostman A., Frijhoff J., Sandin A., Bohmer F. D. // J. Biochem. - 2011. - 150. - P. 345-356.

9. Migliaccio E., Giorgio M., Mele S. et al. // Nature. - 1999. - 402, N 6759. - P. 309-313.

10. Lavrovsky Y., Chatterjee B., Clark R. A., Roy A. K. // Exp. Gerontol. - 2000. - 35. P. 521-532.

11. Speciale A., Chirafisi J., Saija A., Cimino F. // Curr. Mol. Med. - 2011. - 11. - P. 770-789.

12. Diebold I., Flugel D., Becht S. et al. // Antioxid. Redox. Signal. - 2010. - 13. - P. 425-436.

13. Knebel A., Rahmsdorf H. J., Ullrich A., Herrlich P. // EMBO J. - 1996. - 15. - P. 5314-5325.

14. Lander H. M., Hajjar D. P., Hempstead B. L. et al. // J. Biol. Chem. - 1997. - 272. - P. 3234326.

15. Chan D. W., Liu V. W., Tsao G. S. et al. // Carcinogenesis. - 2008. - 29. - P. 1742-1750.

16. McCubrey J. A., Lahair M. M., Franklin R. A. // Antioxid. Redox. Signal. - 2006. - 8, N 9-10. - P. 1775-1789.

17. Handel M. L., Watts C. K., deFazio A. et al. // Proc. Natl. Acad. Sci. USA. - 1995. - 92, N 10. - P. 4497-4501. 
18. Diamond D. A., Parsian A., Hunt C. R. et al. // J. Biol. Chem. - 1999. - 274, N 24. P. 16959-16964.

19. Saitoh M., Nishitoh H., Fujii M. et al. // EMBO J. - 1998. - 17, N 9. - P. 2596-2606.

20. Katagiri K., Matsuzawa A., Ichijo H. // Methods. Enzymol. - 2010. - 474. - P. 277-288.

21. Jin H. O., Seo S. K., Woo S. H. et al. // Lung Cancer. - 2008. - 61, N 3. - P. 317-327.

22. Wang X. T., Pei D. S., Xu J. et al. // Cell Signal. - 2007. - 19, N 9. - P. 1844-1856.

23. Liou G. Y., Storz P. // Free Radic. Res. 2010. - 44, N 5. - P. 479-496.

24. Pham C. G., Papa S., Bubici C. et al. // Curr. Med. Chem. Anti Inflamm. Anti Allergy Agents. - 2005. - 4, N 6. - P. 569-576.

25. Parola M., Robino G., Marra F. et al. // J. Clin. Invest. - 1998. - 102, N 11. - P. 1942-1950.

26. Uchida K., Shiraishi M., Naito Y. et al. // J. Biol. Chem. - 1999. - 274, N 4. - P. 2234-2242.

27. Beyaert R., Cuenda A., Vanden Berghe W. et al. // EMBO J. - 1996. - 15, N8. - P. 1914-1923.

28. Matsukawa J., Matsuzawa A., Takeda K., Ichijo H. // J. Biochem. - 2004. - 136, N 3. P. 261-265.

29. Templeton D. J., Aye M. S., Rady J. et al. // PLoS One. - 2010. - 5, N 11. - e15012.

30. Fresno Vara J. A., Casado E., de Castro J. et al. // Cancer Treat. Rev. - 2004. - 30, N 2. P. 193-204.

31. Nicholson K. M., Anderson N. G. // Cell Signal. - 2002. - 14, N 5. - P. 381-395.

32. Mehdi M. Z., Azar Z. M., Srivastava A. K. // Cell Biochem. Biophys. - 2007. - 47, N 1. P. $1-10$.

33. Shaw M., Cohen P., Alessi D. R. // Biochem. J. - 1998. - 336, Pt 1. - P. 241-246.

34. Wang X., McCullough K. D., Franke T. F., Holbrook N. J. // J. Biol. Chem. - 2000. - 275, N 19. - P. 14624-14631.

35. Lee S. R., Yang K. S., Kwon J. et al. // J. Biol. Chem. - 2002. - 277, N 23. - P. 20336-20342.

36. Huo Y. Y., Li G., Duan R. F. et al. // Free Radic. Biol. Med. - 2008. - 44, N 8. - P. 1578-1591.

37. Redig A. J., Platanias L. C. // Leuk. Lymphoma. - 2008. - 49, N 7. - P. 12551262.

38. Konishi H., Tanaka M., Takemura Y. et al. // Proc. Natl. Acad. Sci. USA. - 1997. - 94, N 21. - P. 11233-11237.

39. Kazanietz M. G. // Biochim. Biophys. Acta. 2005. - 1754, N 1-2. - P. 296-304.

40. Ferreiro D. U., Komives E. A. // Biochemistry. 2010. - 49, N 8. - P. 1560-1567.

41. Morgan M. J., Liu Z. G. // Cell Res. - 2011. 21, N 1. - P. 103-115.
42. Klaunig J. E., Kamendulis L. M. // Annu. Rev. Pharmacol. Toxicol. - 2004. - 44. - P. 239267.

43. Rayet B., Gélinas C. // Oncogene. - 1999. 18, N 49. - P. 6938-6947.

44. Kamata H., Manabe T., Oka Si. et al. // FEBS Lett. - 2002. - 519, N 1-3. - P.231-237.

45. Jamaluddin M., Wang S., Boldogh I. et al. // Cell Signal. - 2007. - 19, N 7. - P. 1419-1433.

46. Ventura C., Maioli M. // Crit. Rev. Eukaryot. Gene Expr. - 2001. - 11, N 1-3. - P. 243-267.

47. Razin E., Szallasi Z., Kazanietz M. G. et al. // Proc. Natl. Acad. Sci. USA. - 1994. - 91, N 16. - P. 7722-7726.

48. Matthews J. R., Kaszubska W., Turcatti G. et al. // Nucleic Acids Res. - 1993. - 21, N 8. P. 1727-1734.

49. Matthews J. R., Wakasugi N., Virelizier J. L. et al. // Nucleic Acids Res. - 1992. - 20, N 15. P. 3821-3830.

50. Pineda-Molina E., Klatt P., Vбzquez J. et al. // Biochemistry. - 2001. - 40, N 47. - P. 1413414142.

51. Kabe Y., Ando K., Hirao S. et al. // Antioxid. Redox Signal. - 2005. - 7, N 3-4. - P. 395403.

52. Kaestner K. H., Knochel W., Martinez D. E. // Genes Dev. - 2000. - 14, N 2. - P. 142-146.

53. Dansen T. B. // Antioxid. Redox Signal. 2011. - 14, N 4. - P. 559-561.

54. Dansen T. B., Smits L. M., van Triest M. H. et al. // Nat. Chem. Biol. - 2009. - 5, N 9. P. 664-672.

55. Taguchi K., Motohashi H., Yamamoto M. // Genes Cells. - 2011. - 16, N 2. - P. 123-140.

56. Cullinan S. B., Zhang D., Hannink M. et al. // Mol. Cell Biol. - 2003. - 23, N 20. - P. 71987209.

57. Zhao C. R., Gao Z. H., Qu X. J. // Cancer Epidemiol. - 2010. - 34, N 5. - P. 523-533.

58. Yamamoto T., Suzuki T., Kobayashi A. et al. // Mol. Cell Biol. - 2008. - 28, N 8. - P. 27582770.

59. Keum Y. S., Jeong W. S., Kong A. N. // Mutat. Res. - 2004. - 555, N 1-2. - P. 191-202.

60. Ни C. J., Wang L. Y., Chodosh L. A. et al. // Mol. Cell Biol. - 2003. - 23, N 24. - P. 93619374.

61. Hara S., Hamada J., Kobayashi C. et al. // Biochem. Biophys. Res. Commun. - 2001. 287, N 4. - P. 808-813.

62. Heikkilä M., Pasanen A., Kivirikko K. I., Myllyharju J. // Cell Mol. Life Sci. - 2011. 68, N 23. - P. 3885-3901.

63. Semenza G. L. // Exp. Physiol. - 2006. - 91, N 5. - P. 803-806. 
64. Epstein A. C., Gleadle J. M., McNeill L. A. et al. // Cell. - 2001. - 107, N 1. - P. 43-54.

65. Bruick R. K., McKnight S. L. // Science. 2001. - 294, N 5545. - P. 1337-1340.

66. Jaakkola P., Mole D. R., Tian Y. M. et al. // Science. - 2001. - 292, N 5516. - P. 468-472.

67. Ivan M., Kondo K., Yang H. et al. // Science. 2001. - 292, N 5516. - P. 464-468.

68. Lando D., Peet D. J., Whelan D. A. et al. // Science. - 2002. - 295, N 5556. - P. 858-861.

69. Kallio P.J., Okamoto K., O’Brien S. et al. // EMBO J. - 1998. - 17, N 22. - P. 6573-6586.

70. Wang G. L., Jiang B. H., Semenza G. L. // Biochem. Biophys. Res. Commun. - 1995. 216, N 2. - P. 669-675.

71. Chen H., Shi H. // FEBS Lett. - 2008. - 582, N 28. - P. 3899-3902.

72. Kietzmann T., Görlach A. // Semin. Cell Dev. Biol. - 2005. - 16, N 4-5. - P. 474-486.

73. Carrero P., Okamoto K., Coumailleau P. et al. // Mol. Cell Biol. - 2000. - 20, N 1. - P. 402-415.

74. Jokilehto T., Jaakkola P. M. // J. Cell Mol. Med. - 2010. - 14, N 4. - P. 758-770.

75. Dimova E. Y., Michiels C., Kietzmann T. // Curr. Pharm. Des. - 2009. - 15, N 33. P. 3867-3877.

76. Görlach A., Diebold I., Schini-Kerth V. B. et al. // Circ. Res. - 2001. - 89, N 1. - P. 47-54.

77. Richard D. E., Berra E., Pouyssegur J. // J. Biol. Chem. - 2000. - 275, N 35. - P. 26765-26771.

78. Fukuda R., Kelly B., Semenza G. L. // Cancer Res. - 2003. - 63, N 9. - P. 2330-2334.

79. Wang F. S., Wang C. J., Chen Y. J. et al. // J. Biol. Chem. - 2004. - 279, N 11. - P. 1033110337.

80. Kietzmann T., Jungermann K., Görlach A. // Thromb. Haemost. - 2003. - 89, N 4. P. 666-673.

81. Gao N., Jiang B. H., Leonard S. S. et al. // J. Biol. Chem. - 2002. - 277, N 47. - P. 4504145048.

82. Liu C., Shi Y., Han Z. et al. // Biochem. Biophys. Res. Commun. - 2003. - 312, N 3. P. 780-786.

83. Marchetti S., Gimond C., Roux D. et al. // J. Cell. Physiol. - 2004. - 199, N 3. - P. 441-450.
84. Carnero A. // Curr. Pharm. Des. - 2010. - 16, N 1. - P. 34-44.

85. Raman M., Chen W., Cobb M. H. // Oncogene. 2007. - 26, N 22. - P. 3100-3112.

86. Ray P. D., Huang B. W., Tsuji Y. // Cell Signal. - 2012. - 24, N 5. - P. 981-990.

87. Gupta S. C., Hevia D., Patchva S. et al. // Antioxid. Redox Signal. - 2012. - 16, N 11. P. 1295-1322.

88. Kong Q., Beel J. A., Lillehei K. O. // Med. Hypotheses. - 2000. - 55, N 1. - P. 29-35.

89. Ramsey M. R., Sharpless N. E. // Nat. Cell Biol. - 2006. - 8, N 11. - P. 1213-1215.

90. Takahashi A., Ohtani N., Yamakoshi K. et al. // Nat. Cell Biol. - 2006. - 8, N 11. - P. 12911297.

91. Luanpitpong S., Talbott S. J., Rojanasakul Y. et al. // J. Biol. Chem. - 2010. - 285, N 50. P. 38832-38840.

92. Pelicano H., Carney D., Huang P. // Drug Resist. Updat. - 2004. - 7, N 2. - P. 97-110.

93. Raj L., Ide T., Gurkar A. U. et al. // Nature. 2011. - 475, N 7355. - P. 231-234.

94. Trachootham D., Alexandre J., Huang P. // Nat. Rev. Drug Discov. - 2009. - 8, N 7. - P. 579591.

95. Berneis K., Bollag W., Kofler M., Lüthy H. // Eur. J. Cancer. - 2004. - 40, N 13. - P. 19281933.

96. Pelicano H., Feng L., Zhou Y. et al. // J. Biol. Chem. - 2003. - 278, N 39. - P. 37832-37839.

97. Azzam E. I., de Toledo S.M., Little J. B. // Curr. Cancer Drug Targets. - 2004. - 4, N 1. P. 53-64.

98. Schafer Z. T., Grassian A. R., Song L. et al. // Nature. - 2009. - 461, N 7260. - P. 109-113.

99. Lu J., Chew E. H., Holmgren A. // Proc. Natl. Acad. Sci. USA. - 2007. - 104, N 30. P. 12288-12293.

100. Agarwala S. S., Glaspy J., O’Day S. J. et al. // J. Clin. Oncol. - 2002. - 20, N 1. - P. 125-133.

101. Yamagishi S., Abe R., Inagaki Y. et al. // Am. J. Pathol. - 2004. - 165, N 6. - P. 1865-1874.

102. Druesne-Pecollo N., Latino-Martel P., Norat T. et al. // Int. J. Cancer. - 2010. - 127, N 1. P. 172-184. 